\title{
A new objective function for the assembly line balancing optimization in terms of workers' global competence
}

\author{
DOI: 10.35530/IT.071.04.1545
}

\section{ABSTRACT - REZUMAT}

\section{A new objective function for the assembly line balancing optimization in terms of workers' global competence}

This paper proposes an optimization model for the Assembly Line Balancing Problem (ALBP) in order to improve the work group choice in clothing industry. Traditionally, ALBP deals with several objectives like minimization of workstations number, minimization of cycle time, maximization of workload smoothness, and maximization of work relatedness...but neglect operators' performance. As the worker competence is crucial to both product quality and productivity, an approach is proposed to balance production line through optimal operators' assignment with the consideration of their skill levels. Based on two criteria, which are the Quality Index "QI" and the Activity "A", each worker was evaluated in each executed operation. From these individual criteria, global indicators of the work group selected were proposed. Applying the Weighted Sum Model (WSM) a more general indicator which is the global Competence Index "Cl " was presented. Using simple linear regression model, the global competence was modelled. Thereafter, the model was validated and justified. The resulting performance indicator allowed predicting the global competence level, comparing different balancing proposals and making an optimal choice. So, a new objective function to maximize can be used in $A L B P$ resolution in order to optimize the selected group capability.

Keywords: Assembly Line Balancing Problem, objective function, Weighed Sum Model, global competence index, simple linear regression model

\section{O nouă funcție obiectiv pentru optimizarea echilibrării liniei de asamblare corelată cu nivelul de competență globală al lucrătorilor}

Acest studiu propune un model de optimizare a problemei de echilibrare a liniei de asamblare (ALBP) pentru a îmbunătăți alegerea grupului de lucru din industria de îmbrăcăminte. În mod tradițional, ALBP tratează mai multe obiective precum minimizarea numărului de stații de lucru, minimizarea timpului de lucru, maximizarea volumului de muncă și maximizarea relației de muncă ... dar neglijează performanțele operatorilor. Întrucât competența lucrătorului este esențială atât pentru calitatea produsului, cât și pentru productivitate, se propune o abordare pentru a echilibra linia de producție prin atribuirea operatorilor optimi cu luarea în considerare a nivelului lor de competență. Pe baza a două criterii, care sunt indicele de calitate „QI” și activitatea „A”, fiecare lucrător a fost evaluat în fiecare operație executată. Din aceste criterii individuale, s-au propus indicatori globali ai grupului de lucru selectat. Folosind modelul sumei ponderate (WSM), a fost prezentat un indicator mai general, care este indicele global de competență " $\mathrm{Cl} g$ ". Folosind un model de regresie liniară simplă, a fost modelată competența globală. Ulterior, modelul a fost validat și justificat. Indicatorul de performanță rezultat a permis preconizarea nivelului de competență globală, compararea diferitelor propuneri de echilibrare și luarea unei decizii optime. Prin urmare, o nouă funcție obiectiv de maximizare poate fi utilizată în rezolvarea ALBP pentru a optimiza capacitatea grupului selectat.

Cuvinte-cheie: problema de echilibrare a liniei de asamblare, funcție obiectiv, model de sumă ponderată, indice de competență globală, model de regresie liniară simplă

\section{INTRODUCTION}

Textile industry is one of the world's numerous industries specially the clothing one [1]. In this sector, every day, managers and workers face globalization and subsequent changes in organizational directions and goals. The clothing production process is based on the sewing, a phase which contains an important number of operations. A sequence of workstations constitutes the sewing line. Every workstation involves one to several tasks assigned to workers according to their capability [1]. This is the assembly line phenomenon developed to meet market requirements in terms of product variability, production rates and costs, cycle times and quality levels. Assembly lines can organize production in three different ways: single model, multi-model and mixed-model assembly lines [2]. The design of a single model assembly is constructed for only one type of product. The mixed-model assembly produces different products at the same time and the multi-model produces a sequence of batches with intermediate setup operations [3-4].The big challenge is to assign tasks to 
workstations and so to workers as equally as possible. Unequal workload among workstations of a sewing line will lead to the increase of both works in process time and waiting time, indicating the increase of both production cycle time and cost [5]. In general, the choice of workers assignment, depending on the task sequence and duration, labour skill levels, the availability of means and the individual preferences of the decision makers, is a highly complex problem [6]. In practice, the decision making is based on past experiences, judgment and intuition which becomes rather difficult and cannot be guaranteed from one manager to another [7]. The human mind is also not capable of perceiving in all details many parameters at a time. Decision making is no more an art where the decision maker can apply mental models to find solution [8-9]. It is gradually becoming more and more scientific. In scientific decision making, mathematical models are applied to find solutions to organizational problems [10]. The decision problem of optimally balancing the assembly work among the workstations with respect to some objective is known as the Assembly Line Balancing Problem (ALBP) [11]. Since assembly line balancing is an NP-hard problem, some heuristic methods are still needed to solve large scale assembly line balancing problems [1]. For several years many research have been developed to solve ALBP. Because of the numerous simplifying assumptions underlying this basic problem, the field of research has traditionally focused on Simple Assembly Line Balancing Problem (SALBP) [12].

\section{The Simple Assembly Line Balancing Problems (SALBP)}

Baybars specified the assumptions underlying SALBP [13]:

(A-1): all input parameters are known with certainty;

(A-2): a task cannot be split among two or more stations;

(A-3): tasks cannot be processed in arbitrary sequences due to technological precedence requirements;

(A-4): all tasks must be processed;

(A-5): all stations under consideration are equipped and manned to process any one of the tasks;

(A-6): the task process times are independent of the station at which they are performed and of the preceding or following;

(A-7): any task can be processed at any station;

(A-8): the total line is considered to be serial with no feeder or parallel subassembly lines or any possible interaction of this type is ignored;

(A-9): the assembly system is assumed to be designed for a unique model of a single product.

Other versions of SALBP are summarized in the table 1.

SALBP-F: A Feasibility $(F)$ problem which is to establish whether or not a feasible line balance exists for a given combination of number of workstations $m$ and cycle time $c$.

\begin{tabular}{|c|c|c|}
\hline \multicolumn{3}{|c|}{ VERSIONS OF SALBP } \\
\hline \multirow{2}{*}{$\begin{array}{c}\text { Number of } \\
\text { workstations } \mathbf{m}\end{array}$} & \multicolumn{2}{|c|}{ Cycle time c } \\
\cline { 2 - 3 } & Given & Minimize \\
\hline Given & SALBP-F & SALBP-2 \\
\hline Minimize & SALBP-1 & SALBP-E \\
\hline
\end{tabular}

SALBP-1: In addition to (A-1)-(A-9), we have: (A-10): the cycle time $c$ is given and fixed. The goal is to minimize the number of workstations $m$.

SALBP-2: The same as SALBP-1 except that instead of $(A-10)$ we have: $(A-11)$ : the number of workstations is given and fixed. The goal is to minimize the cycle time or equivalently, to maximize the production rate. SALBP-E: It combines models SALBP-1 and SALBP-2. The goal is to maximize the assembly line balancing Efficiency $(E)$ by minimizing the number of workstations and cycle time [14].

\section{The General Assembly Line Balancing Problem (GALBP)}

The assumptions of SALBP are very restricting with respect to real-world assembly line systems [15]. Therefore, researchers have recently intensified their efforts to identify, formulate and solve more realistic problems. Any problem of the ALBP type having at least one extended hypothesis of the SALBP has been named in literature the General Assembly Line Balancing Problem (GALBP). The multi-model and mixed-model assembly lines are clear examples. The state-of-the-art articles on GALBP [11, 15-16] described the evolution of the hypotheses and approaches of the proposed resolution. Some authors [15] compared 64 papers related to SALBP and GALBP problems (publications during the period 1955-1985). About twenty years later, there are 146 works dealing only with GALBP type problems [11]. Different additional characteristics have been incorporated in GALBP to get closer to the industry reality. Even real case applications for ALBPs are relatively few in literatures [17]. Boysen et al. classified ALBPs and pointed out that there were less than $5 \%$ articles explicitly solving line balancing of real world assembly systems [18]. In 2006, authors surveyed different studies dealing with many additional characteristics such as cost functions, equipment selection, paralleling, U-shaped line layout, assignment restrictions and stochastic task times [11]. Other studies have worked on maximizing the workload smoothness, for a given number of workstations or maximizing the work relatedness by arranging the tasks in a workstation or even combining these last two objectives [19]. In spite of these efforts, which are referred, to as GALB, there seems to be a wide gap between the academic discussion and practical applications [20]. Conducted studies neglected significant factors affecting the decision making on assembly line balancing in labour intensive industries, such as labour skill levels [5]. The operator factors were rarely considered in solving the 
ALBP. It is widely ignored in real situations of labour intensive industry, such as apparel manufacturing. Even with the optimal task sequence employed, and minimized cycle time obtained, the production line still cannot be balanced in most cases. This is because of the efficiency variance among operators and uncertain efficiency of the same operator in different situations [21]. From a normative side, ISO 9001:2008 provides, for human resources management in Chapter 6.2, that the skills performing activities affecting the product conformity should be identified and that companies should implement adequate actions to meet these skills needs [22]. The workers evaluation and assignment system is an important problem that can significantly affect the future competitiveness and the performance of an organization [23]. In the apparel industry, despite the presence of certain workforce assessing methods, managers have expressed some reservations about these appreciation methods. They expressed their wish to determine objective indicators that would eliminate all subjectivity [24]. In 2014, the skill levels were defined simply by the number of machine types that an operator can perform [5]. For example, worker operating two machine types have a number of skill levels equals 2 . This study focuses on the development of a new objective function which can be used in a further work indented to solve GALBPs. The objective function targets the competence of the whole work group from individual competences. An objective assessment based on measurable criteria is used to judge operators' capability. The ALB optimization may formulate with the objective of maximizing the workers global competence. This optimization makes it possible to work with the best performing group. Thus, this work will serve to minimize defects, increase productivity and improve competitiveness.

\section{MATERIALS AND METHODS}

\section{The studied items}

This work was carried out in a company specialized in automotive textile products. This exporting compa- ny employs 25 persons with an annual production of $2,000,000$ pieces. It makes technical items (security nets, straps, bracelets, gearbox covers) for the automotive and transport industry to several brands (Mercedes Benz, Volkswagen, DAF). This type of items requires a high quality level. In fact, its usage attached to human security expects alertness on its manufacturing quality. This work was achieved in a production line making seat belts for the lower bunks of semitrailer truck cabins. Three seat belt models were used to build the database (figure 1).

\section{Performance indicators of individual skills}

In general, an operator is qualified both by work quality and production capacity. To express the work quality, a Quality Index “QI" (equation 1) was used. Based on Defects Ratio "DR" (equation 2) produced by each worker and a Defect Enhancer Coefficient "DEC" (equation 3) characterizing the weight of each defect, this criterion summarizes the quality level. For the production capacity, the operator Activity "A" (equation 4) may be an indicator [25]:

$$
Q I_{i}=1-\sum_{j}^{n} D E C_{j} \times D R_{j}
$$

where $n$ is the number of defect types.

$$
\begin{gathered}
D R(\%)=\frac{\text { Number of defects }}{\text { Number of controlled pieces }} \times 100 \\
D E C=1+\frac{\text { Defect cost }}{\text { Item cost price }} \\
A_{i}=\frac{\text { Productive time }}{\text { Attendance time }- \text { Time off standard }}
\end{gathered}
$$

\section{Global Performance indicators}

In clothing industry, operators are capable to perform from one to several operations. Therefore, many possible assignments can be envisaged. The resulting work differs from a group to another in terms of defects rate, rejected pieces rate, productivity etc. In practice, the choice is up to experts and in case of use computer software the objectives never target the workers' competence. Thus, to express the global

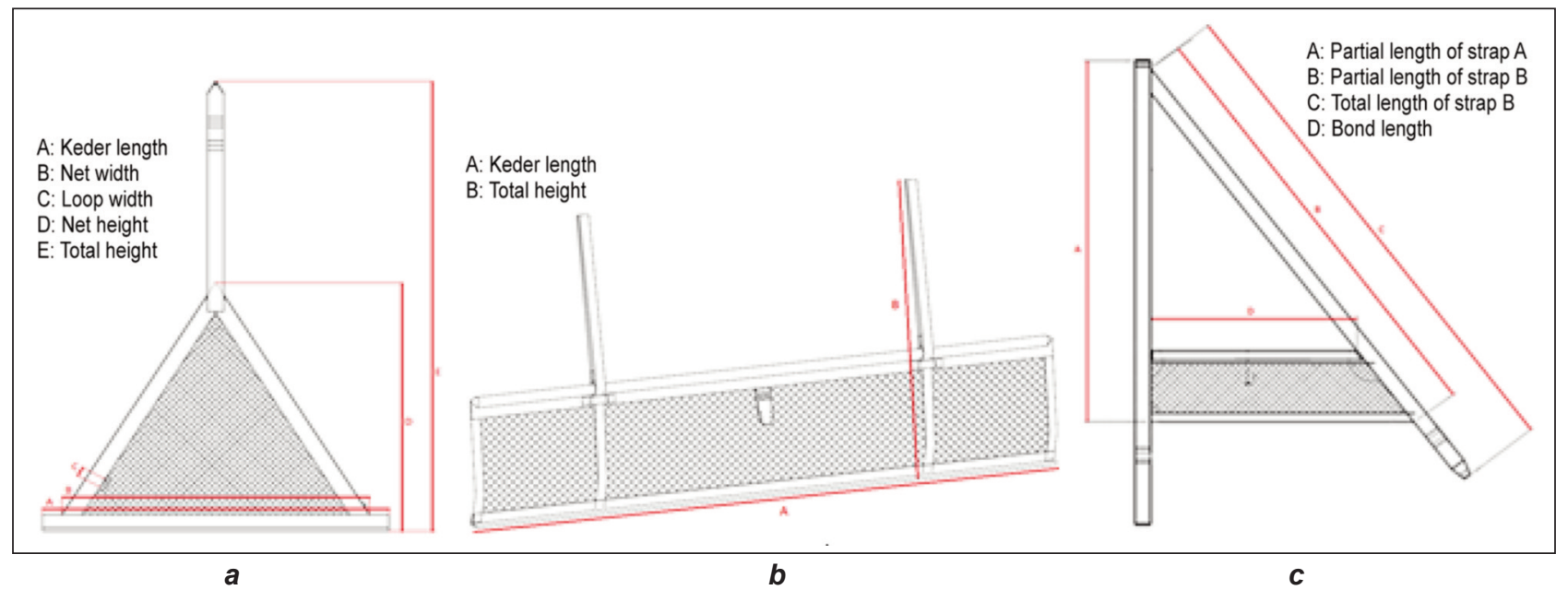

Fig. 1. Seat belt models: $a$ - sketch of model 102; $b$ - sketch of model 109; $c$ - sketch of model 111 
competence of the selected work group from the operators' individual skills performance, the following global indicators were proposed (equations 5, 6 and 7). Global Quality Index was calculated:

$$
Q I_{g}=1-\sum_{i}^{N} \sum_{j}^{n} D E C_{j} \times D R_{j}=1-\left(N-\sum_{i}^{N} Q I_{i}\right)
$$

where $N$ is the number of tasks (if a task is executed by more than one operator $N$ is equal to the operators number). This index expresses the quality level of the selected group since it sums the defects rate produced by all the workers weighted obviously by their DECs.

Global Activity was calculated:

$$
A_{g}=A_{i \text { (latest task })}
$$

The Activity of the worker performing the latest task reflects the group state. In fact, since it is the chain exit the latest workstation describes the produced quantity of the finished product. The latest worker reflects the global Activity even in case of supply disturbance. If the latest task is performed by more than one worker, the global Activity will be the weighted average of workers' Activities.

Global Competence Index was calculated:

$$
\begin{gathered}
C I_{g}=\alpha \times Q I_{g}+\beta \times A_{g}= \\
=\alpha \times\left(1-\sum_{i}^{N} \sum_{j}^{n} D E C_{j} \times D R_{j}\right)+\beta \times A_{i(\text { latest task })}= \\
=\alpha \times\left(1-\left(N-\sum_{i}^{N} Q I_{i}\right)+\beta \times A_{i(\text { latest task })}\right. \\
\alpha+\beta=1
\end{gathered}
$$

where $\alpha$ and $\beta$ are weighting coefficients respectively of $Q I_{g}$ and $A_{g}$.

A more generalized indicator called global Competence Index " $\mathrm{Cl}_{\mathrm{g}}$ " was developed thanks to a Multi-Criteria Decision Making (MCDM) method which is the Weighted Sum Model (WSM) [27-28]. This method summarized both the global Quality Index and the global Activity in a one indicator. It gave also the advantage of weighting the judgment criteria.

\section{Modelling the global competence}

All operators were tested in each operation of the 3 models which they were judged able to perform according to the competency matrices. The advantage in this company is that it works in large series, so, this test lasted for three months in order to assign the operators in different workstations. This allowed widening the study to have a concrete judgment. $Q I_{i}$ and $A_{i}$ which are the mean values of several tests constituted the database.

Afterwards, 5 possible combinations of ALB for each of the 3 selected models were implemented. Each ALB was implemented for a whole day of work. The production was organized for single model assembly line. All operators judged able, according to the competency matrix, to perform tasks were introduced. So, the workers number was given and fixed. A task can be shared by up to 3 operators and an operator can perform up to 3 tasks. ALB indicators like saturations, cycle times, and production rates were not optimized at this level since the main objective was to model the workers' global performance from the individual skills. This does not prevent that the assignments made were feasible and within logical limits discussed with the company to ensure that it could be practiced for our study.

For each proposed ALB and from the database already built, the couple $\left(Q I_{i T H}, A_{i T H}\right)$ was awarded for each operator in each executed task.

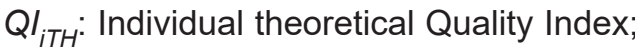

$A_{i T H}$ : Individual theoretical Activity.

Once the ALB is implemented, the couple $\left(Q I_{i E X}, A_{i E X}\right)$ was awarded for each operator from the resulting data of a day's work.

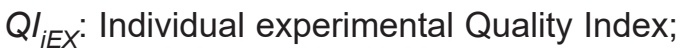

$A_{i E X}$ : Individual experimental Activity.

Global indicators of the whole work group ( $Q I_{g T H}$, $\left.Q I_{g E X}, A_{g T H}, A_{g E X}, C l_{g T H}, C I_{g E X}\right)$ were deduced for each ALB.

QI $_{g T H}$ : Global theoretical Quality Index;

$Q I_{g E X}$ : Global experimental Quality Index;

$A_{g T H}$ : Global theoretical Activity;

$A_{g E X}$ : Global experimental Activity;

$\mathrm{Cl}_{\text {gTH }}$ : Global theoretical Competence Index;

$\mathrm{Cl}_{\text {gEX }}$ : Global experimental Competence Index.

In this study, $Q I_{g}$ and $A_{g}$ were considered of equal weights, so $\alpha=\beta=0.5$.

Using a simple linear regression model, experimental global Competence Indices were expressed by theoretical ones.

\section{RESULTS AND DISCUSSIONS}

\section{Database building}

The database was constructed according to the selected performance indicators $\left(Q_{i}, A_{i}\right)$. For the 3 models each worker was tested in all tasks which can perform. The competency matrix of the model 102 is given bellow. This item was achieved in 8 operations and performed by 6 operators (table 2).

The two following tables detail only the operation "Execute cross box strap".

Table 3 shows the defects database of this operation. Based on defect database, it is clear that the defect "shift stitch in strap side" has the higher DEC. This was caused by the great loss mainly in repair and rechecking time compared to the other defect. Table 4 shows $Q I_{i T H}$ and $A_{i T H}$ for three operators judged capable to perform the operation "Execute cross box strap" according to the competency matrix.

Operators' Performance indicators for all the tasks are illustrated bellow in table 5 .

Similarly, the performance indicators of workers performing model 109 and 111 are given respectively in tables 6 and 7. Model 109 was achieved in 8 operations and performed by 7 operators and model 111 was achieved in 12 operations and performed by 6 operators. 


\begin{tabular}{|c|c|c|c|c|c|c|c|c|}
\hline \multicolumn{9}{|c|}{ COMPETENCY MATRIX (MODEL 102) } \\
\hline \multirow{2}{*}{ No. } & \multirow{2}{*}{ Operation } & \multirow{2}{*}{ Machine } & \multicolumn{6}{|c|}{ Operator } \\
\hline & & & OP1 & OP2 & OP3 & OP4 & OP5 & OP6 \\
\hline 1 & Cut keder & Automatic blade & $\mathrm{x}$ & & $\mathrm{X}$ & $\mathrm{X}$ & & \\
\hline 2 & Fixing the strap on $90 \mathrm{~mm}$ & 1-needle lockstitch machine (301) & $\mathrm{X}$ & & $\mathrm{x}$ & $\mathrm{X}$ & $\mathrm{X}$ & $\mathrm{X}$ \\
\hline 3 & Execute cross box strap & Automate & $\mathrm{X}$ & & & $\mathrm{X}$ & $\mathrm{X}$ & \\
\hline 4 & Apply band and net & 1-needle lockstitch machine (301) & $x$ & $\mathrm{x}$ & $\mathrm{X}$ & $\mathrm{X}$ & & \\
\hline 5 & Cut band ends & Hot cutter & $\mathrm{X}$ & & $\mathrm{X}$ & $\mathrm{X}$ & & \\
\hline 6 & Assemble keder and net & 2-needles lockstitch machine (301) & $\mathrm{X}$ & & $\mathrm{X}$ & $\mathrm{X}$ & & \\
\hline 7 & Execute safety seams & Automate & & & $x$ & $\mathrm{X}$ & & $\mathrm{X}$ \\
\hline 8 & Assemble strap and net & Automate & & & $\mathrm{X}$ & $\mathrm{X}$ & & \\
\hline
\end{tabular}

Table 3

\begin{tabular}{|l|l|l|l|l|l|l|l|l|}
\hline \multicolumn{7}{|c|}{ DEFECTS DATABASE OF THE OPERATION “EXECUTE CROSS BOX STRAP” } \\
\hline \multirow{2}{*}{ Operation } & $\begin{array}{c}\text { Defect } \\
\text { type }\end{array}$ & \multicolumn{1}{|c|}{$\begin{array}{c}\text { Defect repair } \\
\text { method }\end{array}$} & $\begin{array}{c}\text { Defect } \\
\text { repair } \\
\text { material }\end{array}$ & $\begin{array}{c}\text { Repair } \\
\text { material } \\
\text { cost }(\boldsymbol{\epsilon})\end{array}$ & $\begin{array}{c}\text { Defect } \\
\text { repair and } \\
\text { rechecking } \\
\text { time (S) }\end{array}$ & $\begin{array}{c}\text { Repair } \\
\text { time cost } \\
(\boldsymbol{\epsilon})\end{array}$ & $\begin{array}{c}\text { Defect } \\
\text { cost }(\boldsymbol{\epsilon})\end{array}$ & DEC \\
\hline \multirow{2}{*}{$\begin{array}{l}\text { Execute } \\
\text { cross box } \\
\text { strap }\end{array}$} & $\begin{array}{l}\text { Shift stitch in } \\
\text { elastic side }\end{array}$ & $\begin{array}{l}\text { Unthread the elastic } \\
\text { side and redo }\end{array}$ & Thread & 0.004 & 112.82 & 0.150 & 0.194 & 1.050 \\
\cline { 2 - 10 } & $\begin{array}{l}\text { Shift stitch in } \\
\text { strap side }\end{array}$ & $\begin{array}{l}\text { Unthread all the } \\
\text { stitch and redo }\end{array}$ & Thread & 0.009 & 287.82 & 0.384 & 0.433 & 1.111 \\
\hline
\end{tabular}

Table 4

\begin{tabular}{|c|c|c|c|c|c|c|c|c|}
\hline \multicolumn{9}{|c|}{$\begin{array}{l}\text { PERFORMANCE INDICATORS OF OPERATORS EXECUTING THE OPERATION } \\
\text { "EXECUTE CROSS BOX STRAP" }\end{array}$} \\
\hline \multirow[b]{2}{*}{ Operation } & \multirow[b]{2}{*}{ Operator } & \multirow[b]{2}{*}{$\begin{array}{l}\text { Number of } \\
\text { controlled } \\
\text { pieces }\end{array}$} & \multicolumn{2}{|c|}{ Number of defects } & \multicolumn{2}{|c|}{ DEC } & \multirow[b]{2}{*}{$\mathrm{QI}_{\mathrm{iTH}}$} & \multirow[b]{2}{*}{$\mathbf{A}_{\mathrm{iTH}}$} \\
\hline & & & $\begin{array}{l}\text { Skipped stitch } \\
\text { or Balloon } \\
\text { stitch }\end{array}$ & $\begin{array}{l}\text { Backstitch } \\
\text { missing }\end{array}$ & $\begin{array}{c}\text { Shift stitch } \\
\text { in elastic } \\
\text { side }\end{array}$ & $\begin{array}{l}\text { Shift stitch } \\
\text { in strap } \\
\text { side }\end{array}$ & & \\
\hline \multirow{3}{*}{$\begin{array}{l}\text { Execute } \\
\text { cross box } \\
\text { strap }\end{array}$} & OP1 & 840 & 12 & 0 & \multirow{3}{*}{1.050} & \multirow{3}{*}{1.111} & 0.859 & 0.653 \\
\hline & OP4 & 770 & 22 & 44 & & & 0.907 & 0.972 \\
\hline & OP5 & 840 & 18 & 90 & & & 0.985 & 0.972 \\
\hline
\end{tabular}

\begin{tabular}{|c|c|c|c|c|c|c|c|c|c|c|c|c|c|}
\hline \multicolumn{14}{|c|}{ OPERATORS' PERFORMANCE INDICATORS FOR MODEL 102} \\
\hline \multirow{3}{*}{ No. } & \multirow{3}{*}{ Operation } & \multicolumn{12}{|c|}{ Operator } \\
\hline & & \multicolumn{2}{|c|}{ OP1 } & \multicolumn{2}{|c|}{ OP2 } & \multicolumn{2}{|c|}{ OP3 } & \multicolumn{2}{|c|}{ OP4 } & \multicolumn{2}{|c|}{ OP5 } & \multicolumn{2}{|c|}{ OP6 } \\
\hline & & $\mathbf{Q I}_{\mathrm{iTH}}$ & $\mathbf{A}_{\mathrm{iTH}}$ & $\mathbf{Q I}_{\mathrm{iTH}}$ & $A_{\text {iTH }}$ & $\mathbf{Q I}_{\mathrm{iTH}}$ & $\mathbf{A}_{\mathrm{iTH}}$ & $\mathbf{Q I}_{\mathrm{iTH}}$ & $A_{\text {iTH }}$ & $\mathbf{Q I}_{\mathrm{iTH}}$ & $A_{\text {iTH }}$ & $\mathbf{Q I}_{\mathrm{iTH}}$ & $A_{\text {iTH }}$ \\
\hline 1 & Cut keder & 0.986 & 0.758 & & & 0.828 & 0.692 & 0.833 & 0.667 & & & & \\
\hline 2 & Fix the strap on $90 \mathrm{~mm}$ & 0.913 & 0.767 & & & 0.993 & 0.833 & 0.930 & 0.800 & 0.870 & 1.000 & 1.000 & 0.767 \\
\hline 3 & Execute cross box strap & 0.859 & 0.653 & & & & & 0.907 & 0.972 & 0.985 & 0.972 & & \\
\hline 4 & Apply band and net & 0.803 & 0.583 & 0.993 & 0.950 & 0.964 & 0.950 & 0.838 & 0.950 & & & & \\
\hline 5 & Cut band ends & 0.804 & 0.972 & & & 0.655 & 0.583 & 0.641 & 0.583 & & & & \\
\hline 6 & Assemble keder and net & 0.926 & 0.875 & & & 0.897 & 0.750 & 0.955 & 0.597 & & & & \\
\hline 7 & Execute safety seams & & & & & 0.998 & 0.889 & 1.000 & 0.778 & & & 0.979 & 1.000 \\
\hline 8 & Assemble strap and net & & & & & 0.982 & 0.857 & 0.886 & 1.000 & & & & \\
\hline
\end{tabular}




\begin{tabular}{|c|c|c|c|c|c|c|c|c|c|c|c|c|c|c|}
\hline \multicolumn{15}{|c|}{ OPERATORS' PERFORMANCE INDICATORS FOR MODEL 109} \\
\hline \multirow{3}{*}{ Operation } & \multicolumn{14}{|c|}{ Operator } \\
\hline & \multicolumn{2}{|c|}{ OP2 } & \multicolumn{2}{|c|}{ OP4 } & \multicolumn{2}{|c|}{ OP6 } & \multicolumn{2}{|c|}{ OP7 } & \multicolumn{2}{|c|}{ OP8 } & \multicolumn{2}{|c|}{ OP9 } & \multicolumn{2}{|c|}{ OP10 } \\
\hline & $\mathrm{QI}_{\mathrm{iTH}}$ & $A_{\mathrm{iTH}}$ & $\mathbf{Q I}_{\mathrm{iTH}}$ & $\mathbf{A}_{\mathrm{iTH}}$ & $\mathbf{Q I}_{\mathrm{iTH}}$ & $A_{i T H}$ & $\mathbf{Q I}_{\mathrm{iTH}}$ & $A_{i T H}$ & $\mathbf{Q I}_{\mathrm{iTH}}$ & $A_{\mathrm{iTH}}$ & $\mathbf{Q I}_{\mathrm{iTH}}$ & $\mathrm{A}_{\mathrm{iTH}}$ & $\mathbf{Q I}_{\mathrm{iTH}}$ & $A_{i T H}$ \\
\hline Cut keder & & & & & 0.991 & 0.778 & 0.994 & 0.944 & 0.986 & 0.778 & & & 0.989 & 0.778 \\
\hline $\begin{array}{l}\text { Cut and burn } \\
\text { elastic }\end{array}$ & & & & & 0.988 & 0.839 & 0.998 & 0.968 & 0.982 & 0.839 & & & & \\
\hline $\begin{array}{l}\text { Apply small band } \\
\text { and net }\end{array}$ & & & & & 0.999 & 1.000 & 0.998 & 1.000 & 0.996 & 1.000 & & & & \\
\hline $\begin{array}{l}\text { Apply elastic and } \\
\text { band }\end{array}$ & & & 0.979 & 1.364 & 0.967 & 1.000 & & & 0.982 & 1.000 & & & & \\
\hline $\begin{array}{l}\text { Apply band and } \\
\text { net (insert } \\
\text { caoutchou) }\end{array}$ & 0.952 & 0.550 & & & & & & & & & 0.960 & 0.750 & 0.973 & 0.850 \\
\hline $\begin{array}{l}\text { plate the strap on } \\
\text { net }\end{array}$ & & & 0.987 & 1.111 & & & 0.989 & 1.000 & 0.971 & 0.933 & 0.968 & 0.933 & & \\
\hline $\begin{array}{l}\text { Assemble keder } \\
\text { and net (insert } \\
\text { label) }\end{array}$ & & & & & & & & & 0.960 & 0.556 & & & 0.972 & 0.556 \\
\hline $\begin{array}{l}\text { Execute safety } \\
\text { seams on } 4 \text { sides }\end{array}$ & & & 0.990 & 1.000 & 0.986 & 1.000 & 0.983 & 1.000 & 0.980 & 0.917 & 0.991 & 0.917 & & \\
\hline
\end{tabular}

\begin{tabular}{|c|c|c|c|c|c|c|c|c|c|c|c|c|}
\hline \multicolumn{13}{|c|}{ OPERATORS' PERFORMANCE INDICATORS FOR MODEL 109} \\
\hline \multirow{3}{*}{ Operation } & \multicolumn{12}{|c|}{ Operator } \\
\hline & \multicolumn{2}{|c|}{ OP3 } & \multicolumn{2}{|c|}{ OP4 } & \multicolumn{2}{|c|}{ OP5 } & \multicolumn{2}{|c|}{ OP6 } & \multicolumn{2}{|c|}{ OP8 } & \multicolumn{2}{|c|}{ OP10 } \\
\hline & $\mathbf{Q I}_{\mathrm{iTH}}$ & $\mathrm{A}_{\mathrm{iTH}}$ & $\mathbf{Q I}_{\mathrm{iTH}}$ & $A_{\text {iTH }}$ & $\mathbf{Q I}_{\mathrm{iTH}}$ & $\mathrm{A}_{\mathrm{iTH}}$ & $\mathbf{Q I}_{\mathrm{iTH}}$ & $\mathrm{A}_{\mathrm{iTH}}$ & $\mathbf{Q I}_{\mathrm{iTH}}$ & $A_{\text {iTH }}$ & $\mathbf{Q I}_{\mathrm{iTH}}$ & $\mathrm{A}_{\mathrm{iTH}}$ \\
\hline Apply small band and net & & & 0.987 & 0.857 & & & 0.994 & 0.857 & 1.000 & 1.000 & 0.978 & 0.814 \\
\hline Apply band, sponge and net & & & 0.984 & 0.778 & & & 0.990 & 0.722 & 0.997 & 0.889 & 0.974 & 0.711 \\
\hline Fix strap B & & & 0.997 & 1.000 & 0.980 & 0.917 & 0.994 & 1.000 & & & & \\
\hline Execute butterfly design & & & 1.000 & 1.000 & 0.983 & 0.917 & 0.991 & 1.000 & & & & \\
\hline Apply elastic on strap A and B & & & 0.858 & 1.364 & & & 0.898 & 0.909 & & & & \\
\hline Cut band ends & & & 0.870 & 1.000 & 0.808 & 0.917 & 0.847 & 0.958 & 0.839 & 1.000 & & \\
\hline Mark strap A and B & & & 0.997 & 1.000 & & & 0.997 & 1.000 & 0.991 & 1.000 & & \\
\hline \begin{tabular}{|l|} 
Plate strap B on left side of the \\
net and fix Velcro B \\
\end{tabular} & & & 0.979 & 1.111 & 0.930 & 1.000 & & & & & & \\
\hline $\begin{array}{l}\text { Plate strap A on right side of the } \\
\text { net and fix Velcro A }\end{array}$ & & & 0.982 & 1.111 & 0.924 & 1.000 & & & & & & \\
\hline Mark the end of strap A and B & 0.985 & 1.000 & 0.994 & 1.000 & 0.967 & 1.000 & 0.997 & 1.000 & 0.988 & 1.000 & 0.982 & 1.000 \\
\hline Cut strap B ends & & & 0.997 & 0.944 & & & 0.997 & 1.000 & 1.000 & 1.000 & & \\
\hline $\begin{array}{l}\text { Assemble strap A and B and } \\
\text { insert label }\end{array}$ & 0.982 & 0.833 & & & & & 0.991 & 0.972 & 1.000 & 0.972 & & \\
\hline
\end{tabular}

\section{Global performance assessment}

An example of an ALB for the model 102 is proposed and detailed in table 8 . This item was achieved in 393 seconds including the time of peel, control and pack. Those tasks were added to the initial operations which became 11. The control Agent (CA) was also added to the selected group.

The saturation varies from $89.06 \%$ to $110.43 \%$ which were acceptable in our study.
The following table demonstrates the couple $\left(Q l_{i T H}\right.$, $A_{i T H}$ ) estimated for each worker assigned according to the ALB proposed above. These theoretical values were extracted from the database (table 9).

Theoretical global indicators of this ALB were deduced using the equations 5,6 and 7 .

$$
\begin{aligned}
Q I_{\text {gTH }}= & 1-(8-(0.986+0.993+0.985+0.985 \\
& +0.804+0.897+0.979+0.886)=0.523 \\
A_{\text {gTH }}= & 1.000 \\
C l_{\text {gTH }}= & 0.5 \times 0.523+0.5 \times 1.000=0.762
\end{aligned}
$$




\begin{tabular}{|c|c|c|c|c|c|c|c|c|c|}
\hline \multicolumn{10}{|c|}{ ALB FOR MODEL 102} \\
\hline \multirow{3}{*}{ No. } & \multirow{3}{*}{$\begin{array}{c}\text { ON } \\
\text { FB } \\
\text { Operation }\end{array}$} & \multirow{3}{*}{$\begin{array}{c}7 \\
56.14 \\
\text { Time (s) }\end{array}$} & \multirow{2}{*}{\multicolumn{7}{|c|}{ Operator }} \\
\hline & & & & & & & & & \\
\hline & & & OP1 & OP2 & OP3 & OP4 & OP5 & OP6 & CA \\
\hline 1 & Cut keder & 15 & 15 & & & & & & \\
\hline 2 & Fixing the strap on $90 \mathrm{~mm}$ & 12 & & & 12 & & & & \\
\hline 3 & Execute cross box strap & 50 & & & & & 50 & & \\
\hline 4 & Apply band and net & 60 & & 60 & & & & & \\
\hline 5 & Cut band ends & 20 & 20 & & & & & & \\
\hline 6 & Assemble keder and net & 50 & & & 50 & & & & \\
\hline 7 & Execute safety seams & 40 & & & & & & 40 & \\
\hline 8 & Peel and control (intermidiary) & 45 & & & & & & 15 & 30 \\
\hline 9 & Assemble strap and net & 51 & & & & 51 & & & \\
\hline 10 & Control (final) & 30 & & & & & & & 30 \\
\hline 11 & Pack & 20 & 20 & & & & & & \\
\hline & TT & 393 & & & & & & & \\
\hline & Workload (s) & & 55.00 & 60.00 & 62.00 & 51.00 & 50.00 & 55.00 & 60.00 \\
\hline & Saturation (\%) & & 97.96 & 106.87 & 110.43 & 90.84 & 89.06 & 97.96 & 106.87 \\
\hline
\end{tabular}

Note: ON - Operator Number, TT - Total time, FB - Fragmentation Base $\left(F B=\frac{T T}{\mathrm{ON}}\right)$.

Table 9

THEORETICAL OPERATORS' PERFORMANCE INDICATORS FOR THE PROPOSED ALB

\begin{tabular}{|c|l|c|c|c|}
\hline No. & \multicolumn{1}{|c|}{ Operation (task) } & Operator & $\mathbf{Q I}_{\mathrm{iTH}}$ & $\mathbf{A}_{\mathrm{iTH}}$ \\
\hline 1 & Cut keder & OP1 & 0.986 & 0.758 \\
\hline 2 & $\begin{array}{l}\text { Fixing the strap on } \\
90 \mathrm{~mm}\end{array}$ & OP3 & 0.993 & 0.833 \\
\hline 3 & $\begin{array}{l}\text { Execute cross box } \\
\text { strap }\end{array}$ & OP5 & 0.985 & 0.972 \\
\hline 4 & Apply band and net & OP2 & 0.993 & 0.950 \\
\hline 5 & Cut band ends & OP1 & 0.804 & 0.972 \\
\hline 6 & $\begin{array}{l}\text { Assemble keder and } \\
\text { net }\end{array}$ & OP3 & 0.897 & 0.750 \\
\hline 7 & Execute seams safety & OP6 & 0.979 & 1.000 \\
\hline 8 & $\begin{array}{l}\text { Assemble strap and } \\
\text { net }\end{array}$ & OP4 & 0.886 & 1.000 \\
\hline
\end{tabular}

The global competence resulting from this proposed ALB was estimated at 0.762 . Having a global performance indicator in terms of quality and productivity of a selected group is a great advantage. It remains to model this global competence in order to rely on the resulting data.

\section{Simple linear regression model}

For each model, 5 ALBs were implemented. For each ALB, $\mathrm{Cl}_{g T H}$ was estimated from the database already built and $\mathrm{Cl}_{g E X}$ was calculated after an entire day's work. A linear relationship between $\mathrm{Cl}_{g E X}$ and $\mathrm{Cl}_{g T H}$ was established. Taking the ALB detailed in the previous section, the assignments were practiced and at the end of the day the couple $\left(Q I_{i E X}, A_{i E X}\right)$ was obtained as follow.
Table 10

EXPERIMENTAL OPERATORS' PERFORMANCE INDICATORS FOR THE PROPOSED ALB

\begin{tabular}{|c|l|c|c|c|}
\hline No. & \multicolumn{1}{|c|}{ Operation (task) } & Operator & $\mathbf{Q I}_{\text {iEX }}$ & $\mathbf{A}_{\text {iEX }}$ \\
\hline 1 & Cut keder & OP1 & 0.925 & 0.708 \\
\hline 2 & $\begin{array}{l}\text { Fixing the strap on } \\
90 \text { mm }\end{array}$ & OP3 & 1.000 & 0.783 \\
\hline 3 & $\begin{array}{l}\text { Execute cross box } \\
\text { strap }\end{array}$ & OP5 & 0.984 & 0.986 \\
\hline 4 & Apply band and net & OP2 & 1.000 & 1.000 \\
\hline 5 & Cut band ends & OP1 & 0.688 & 0.622 \\
\hline 6 & $\begin{array}{l}\text { Assemble keder and } \\
\text { net }\end{array}$ & OP3 & 0.979 & 0.833 \\
\hline 7 & Execute seams safety & OP6 & 0.989 & 1.000 \\
\hline 8 & $\begin{array}{l}\text { Assemble strap and } \\
\text { net }\end{array}$ & OP4 & 0.985 & 1.043 \\
\hline
\end{tabular}

Based also on the equations 5, 6 and 7, experimental global indicators calculation gives the following values:

$$
\begin{aligned}
Q l_{g E X}= & 1-(8-(0.925+1.000+0.984+1.000+ \\
& +0.688+0.979+0.989+0.985)=0.549 \\
A_{g E X}= & 1.043 \\
C l_{g E X}= & 0.5 \times 0.549+0.5 \times 1.043=0.796
\end{aligned}
$$

By the same way, the calculations were done to get the global indicators for 4 other ALBs of the model 102 and for 5 ALBs of the models 109 and 111. Table 11 summarizes the statistical results for the 3 models. By presenting the experimental values as a function of the theoretical ones for $\mathrm{Cl}_{g}$ (figure 2), we conclude that the global competence is modelled since there is a high regression coefficient $\left(R^{2}=92 \%\right)$. 
GLOBAL INDICATORS FOR THE 15 ALBS OF THE 3 MODELS

\begin{tabular}{|c|c|c|c|c|c|c|c|}
\hline Model & ALB & $\mathrm{QI}_{\mathrm{gTH}}$ & $A_{\mathrm{gTH}}$ & $\mathrm{Cl}_{\mathrm{gTH}}$ & $\mathrm{QI}_{\mathrm{gEX}}$ & $\mathbf{A}_{\mathrm{gEX}}$ & $\mathrm{Cl}_{\mathrm{gEX}}$ \\
\hline \multirow{5}{*}{102} & 1 & 0.523 & 1.000 & 0.762 & 0.549 & 1.043 & 0.796 \\
\hline & 2 & 0.269 & 0.857 & 0.563 & 0.396 & 1.000 & 0.698 \\
\hline & 3 & 0.090 & 0.857 & 0.474 & 0.093 & 1.000 & 0.547 \\
\hline & 4 & -0.443 & 0.857 & 0.207 & -0.068 & 1.000 & 0.466 \\
\hline & 5 & -0.064 & 1.000 & 0.468 & 0.169 & 1.000 & 0.585 \\
\hline \multirow{5}{*}{109} & 1 & 0.770 & 0.917 & 0.844 & 0.714 & 0.933 & 0.824 \\
\hline & 2 & 0.748 & 0.958 & 0.853 & 0.708 & 0.970 & 0.839 \\
\hline & 3 & 0.749 & 1.000 & 0.875 & 0.708 & 1.000 & 0.854 \\
\hline & 4 & 0.788 & 0.917 & 0.853 & 0.738 & 0.967 & 0.853 \\
\hline & 5 & 0.732 & 0.917 & 0.825 & 0.645 & 0.950 & 0.798 \\
\hline \multirow{5}{*}{111} & 1 & 0.467 & 0.972 & 0.720 & 0.543 & 1.000 & 0.772 \\
\hline & 2 & 0.712 & 0.972 & 0.842 & 0.818 & 1.000 & 0.909 \\
\hline & 3 & 0.498 & 0.972 & 0.735 & 0.601 & 1.027 & 0.814 \\
\hline & 4 & 0.681 & 0.972 & 0.827 & 0.824 & 0.944 & 0.884 \\
\hline & 5 & 0.578 & 0.972 & 0.775 & 0.742 & 1.000 & 0.871 \\
\hline
\end{tabular}

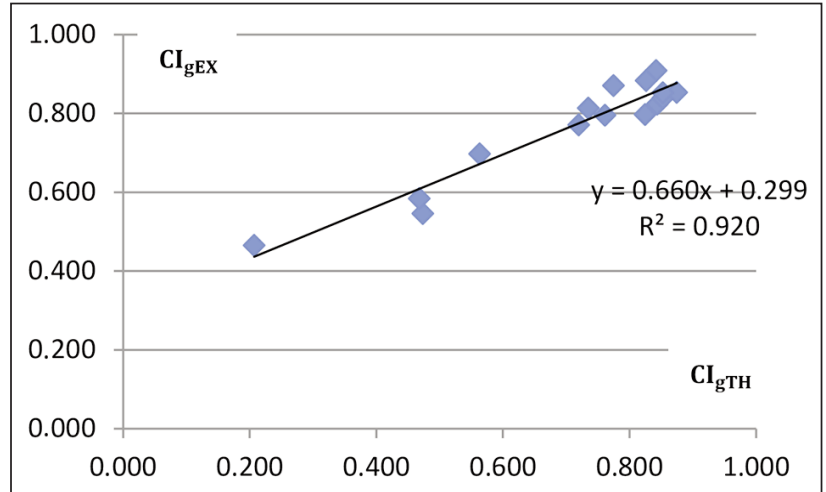

Fig. 2. $\mathrm{Cl}_{g E X}$ as a function of $\mathrm{Cl}_{g T H}$ for the $15 \mathrm{ALBs}$

According to the regression analysis made by the Minitab software, the regression equation is given in equation 8 as follow:

$$
C l_{g E X}=0.660 \mathrm{Cl}_{g T H}+0.299
$$

In the order to judge if the parameters' effect on the measured answer $\left(\mathrm{Cl}_{g E X}\right)$ is statistically significant, the variance analysis is an important test in this survey [28-29]. This test consists to calculate a statistical $F$ from the coefficients of the established model and then to compare it to statistical tables of Snedecor law [30]. Thereafter, from $F$, another $P$ statistic can be calculated. In fact:

If $P<1 \%$ : the parameter is highly significant;

If $1 \% \leq P \leq 5 \%$ : the parameter is significant;

If $P>5 \%$ : the parameter is not significant.

Table 12 reveals $P$-value given directly by the Minitab software.

Regarding table 12, P-value is null for $\mathrm{Cl}_{g E X}, \mathrm{Cl}_{g T H}$ and the constant. Then, we deduce that all the model parameters are highly significant.
Table 12

\begin{tabular}{|c|c|}
\hline \multicolumn{2}{|c|}{ RESULT OF ANALYSIS OF THE VARIANCE } \\
\hline Parameter & P-value \\
\hline ClgEX & 0.000 \\
\hline ClgTH & 0.000 \\
\hline Constant & 0.000 \\
\hline
\end{tabular}

\section{Model validation}

To validate this model, practical method was used. It consists in determining the average absolute relative error between the experimental values given by the linear model $\left(\widetilde{C I_{g E X}}\right)$ and those real; extracted after a day's work $\left(\mathrm{Cl}_{g E X}\right)$. The Mean Absolute Percentage Error (MAPE) is the average of errors; deviations in absolute value from the real experimental values (equation 9).This value represents a practical comparison indicator to judge whether the forecast model is good [31-32]:

$$
\text { Error(\%) }=\frac{C l_{g E X}-\widetilde{C l_{g E X}}}{C l_{g E X}} \times 100
$$

where $\widetilde{C I_{g E X}}$ is the Global experimental competence Index calculated from the linear model.

In order to implement it, 3 other ALBs are implemented; an ALB for each model. Table 13 recaps the main results.

The MAPE is equal to $2.5 \%$, which considered small. The statistical data confirmed that the theoretical and experimental values were close. So, the result of testing and predicting global competence for other ALBs using our model was well verified. Thus, the simple linear regression model was well justified and the findings showed the high significance of this study effectiveness. Considering that the regression 
AVERAGE ERRORS OF THE REGRESSION MODEL FOR 3 OTHER ALBS

\begin{tabular}{|c|c|c|c|c|}
\hline Model & $\mathbf{C I}_{\text {gTH }}$ & $\widetilde{\mathbf{C I}_{\text {gEX }}}$ & $\mathbf{C l}_{\text {gEX }}$ & Error \\
\hline 102 & 0.598 & 0.694 & 0.673 & $3.1 \%$ \\
\hline 109 & 0.884 & 0.883 & 0.866 & $1.9 \%$ \\
\hline 111 & 0.813 & 0.836 & 0.857 & $2.4 \%$ \\
\hline
\end{tabular}

coefficient was very high and the errors were low, we have ensured the validity of the obtained regression model. Therefore, the ALB optimization with the consideration of operators' performance is given by the following objective function (equation 10).

$$
\begin{gathered}
\text { Maximize } C I_{g}=\text { Maximize }\left(\alpha \times Q I_{g}+\beta \times A_{g}\right)= \\
=\text { Maximize }\left(\alpha \times\left(1-\sum_{i}^{N} \sum_{j}^{n} D E C_{j} \times D R_{j}\right)+\right. \\
\left.+\beta \times A_{i(\text { latest task })}\right)= \\
=\text { Maximize }\left(\alpha \times\left(1-\left(N-\sum_{j}^{N} Q I_{i}\right)\right)+\beta \times A_{i(\text { latest task })}\right)
\end{gathered}
$$

By summarizing both the quality level and the production capacity, the proposed objective function guarantees working with the most performing group.

\section{CONCLUSIONS}

This paper proposed an optimal work group choice solution for solving assembly line balancing problems with the consideration of the operators' skills. Using objective performance indicators, which are the Quality Index "QI," and the Activity " $A_{i}$ ", workers' skills were defined and measured. Through these individual indicators, a global Quality Index "QI " and a global Activity " $A_{g}$ " were proposed to express the performance of the whole selected work group. Weighed Sum Model "WSM" was used to combine those two indicators in only one which is the global Competence Index " $\mathrm{Cl}_{\mathrm{g}}$ ". This was modelled by a regression equation. Due to the regression coefficient and the $\mathrm{P}$-value, the global competence was considered modelled and significant.

By computing the mean absolute relative error of new implemented ALBs, the model was validated. Thanks to this work it became possible to evaluate and estimate the selected group performance level for any proposed balancing. Optimizing the balancing choice in terms of workers' skills is simply maximizing $\mathrm{Cl}_{\mathrm{g}}$. This study could be extended in several directions. An extension would be considering an objective function in heuristic method algorithms to solve ALBP. Moreover, this study deals with ALBP of single model and working with mixed-model or multi-model is also the extension of further researches.

\section{REFERENCES}

[1] Chen, J.C., Chen, C.C., Su, L.H., Wu, H.B., Sun, C.J., Assembly line balancing in garment industry, In: Expert Systems with Applications, 2012, 39, 10073-10081

[2] Eryuruk, S.H., Kalaoglu, F., Baskak, M., Assembly Line Balancing in a Clothing Company, In: Fibres \& Textiles in Eastern Europe, 2008, 16, 1, 66

[3] Scholl, A., Becker, C., State-of-The-Art Exact and Heuristic Solution Procedures for Simple Assembly Line Balancing, In: European Journal of Operational Research, 2004, 168, 666-693

[4] Adeppa, A., A Study on Basics of Assembly Line Balancing, In: International Journal on Emerging Technologies, (Special Issue on NCRIET-2015), 2015, 6, 2, 294-297

[5] Chen, J.C., Chen, C.C., Lin, Y.J., Lin, C.J., Chen, T.Y., Assembly Line Balancing Problem of Sewing Lines in Garment Industry, International Conference on Industrial Engineering and Operations Management Bali, Indonesia, 2014

[6] Afshari, A.R., Mojahed, M., Simple Additive Weighting Approach to Personnel Selection Problem, In: International Journal of Innovation and Technology Management, 2010, 1, 5, 511-515

[7] Agpak, K., Gökçen, H., Assembly line balancing: Two resource constrained cases, In: International Journal of Production Economics, 2005, 96, 129-140

[8] Jebali, N., Babay Dhouib, A., Ben Hassen, M., Modeling the overall seam quality of woven cotton fabri, In: International Journal of Applied Research on Textile, 2016, 4, 1, 47-61

[9] Souid, H., Sahnoun, M., Babay, A., Cheikhrouhou, M., A Generalized Model for Predicting Yarn Global Quality Index, In: The Open Textile Journal, 2012, 5, 6, 8-13

[10] Habiba U., Asghar, S., A survey on multi-criteria decision making approaches, International Conference on Emerging Technologies, Islamabad, Pakistan, 2009

[11] Becker, C., Scholl, A., A survey on problems and methods in generalized assembly line balancing, In: European Journal of Operational Research, 2006, 168, 694-715

[12] Boysen, N., Fliedner, M., Scholl, A., A classification of assembly line balancing problems, Arbeits- und Diskussionspapiere der Wirtschaftswissenschaftlichen Fakultät der Friedrich-Schiller-Universität Jena, 2006

[13] Baybars, I., A survey of exact algorithms for the simple assembly line balancing problem, In: Management Science, 1986, 32, 8

[14] Wei, N.C., Chao, I.M., A solution procedure for type E simple assembly line balancing problem, In: Computers \& Industrial Engineering, 2011, 61, 824-830

[15] Ghosh, S., Gagnon, R.J., A comprehensive literature review and analysis of the design, balancing and scheduling of assembly systems, In: International Journal of Production Research, 1989, 27, 4, 637-670 
[16] Rekiek, B., de Lit, P., Delchambre, A., Hybrid assembly line design and user's preferences, In: International Journal of Production Research, 2002, 40, 1095-1111

[17] Guschinskaya, O., Dolgui, A., Equilibrage de lignes de production, In: Journal Européen des Systèmes Automatisé, 2010, 44, 1079-1117

[18] Boysen, N., Fliedner, M., Scholl, A., Assembly line balancing: Which model to use when?, In: International Journal of Production Economics, 2008, 111, 509-528

[19] Boysen, N., Fliedner, M., Scholl, A., A classification of assembly line balancing problems, In: European Journal of Operational Research, 2007, 183, 674-693

[20] Scholl, A., Simple Assembly Line balancing-Heuristic Approaches, In: Journal of Heuristics, 1996, 2, 217-244

[21] Song, B.L., Wong, W.K., Fan, J.T., Chan., S.F., A recursive operator allocation approach for assembly line-balancing optimization problem with the consideration of operator efficiency, In: Computers \& Industrial Engineering, 2006, 51, 585-608

[22] ISO 9001, Chapter 6.2 human resources, 2008

[23] Golec, A., Kahya, E., A fuzzy model for competency-based employee evaluation and selection, In: Computers \& Industrial Engineering, 2007, 52, 143-161

[24] Savall, H., Zardet, V., Maîtriser les coûts et les performances cachées, 2003, 184-185

[25] Chourabi, Z., Khedher, F., Babay, A., Cheikhrouhou, M., Objective evaluation of workforce global performance by determining a new Competence Index, International Conference of Applied Research on Textile (CIRAT-7), Hammamet, Tunisia, 2016

[26] Afshari, A.R., Mojahed, M., Simple Additive Weighting Approach to Personnel Selection Problem, In: International Journal of Innovation and Technology Management, 2010, 5, 511-515

[27] Adriyendi, Multi-Attribute Decision Making Using Simple Additive Weighting and Weighted Product in Food Choice, In: I.J. Information Engineering and Electronic Business, 2015, 6, 8-14

[28] Miliken, G., Johnson, D., Analysis of Messy Data, In: Designed Experiments Van Reinhold, 1984, 1

[29] Nelson, P., A Comparison of Sample seizes for the analysis of means and analysis of variances, In: Journal of Quality Technology, 1983, 15, 33-39

[30] Olshen, R., The conditional level of the F-test, In: Journal of the American Association, 1973, 68, 692-698

[31] El-Ghezal, S., Sahnoun, M., Babay, A., Cheikhrouhou, M., Schacher, L., Adolphe, D., Predicting compression and surfaces properties of knits using fuzzy and neural networks techniques, In: International Journal of Clothing Science and Technology, 2011, 23, 5, 294-309

[32] Malek, S., Khedher, F., Jaouachi, B., Cheikhrouhou, M., Determination of a sewing quality index of denim fabrics, In: The Journal of The Textile Institute, 2017, 3, 2, 1-13

Authors:

ZOUHOUR CHOURABI, AMEL BABAY, FAOUZI KHEDHER, MORCHED CHEIKHROUHOU

Laboratory of Textile Engineering, University of Monastir, 5000, Tunisia

email: Igtex.secretaire@gmail.com

Corresponding author:

ZOUHOUR CHOURABI

email: zouhour.chourabi@gmail.com 